\title{
The Influence of Foreign Currency Volatility on Stok Return and Cash Flows: An Empirical Study in Indonesia Listed Companies
}

\author{
NYOMAN ARDHIANTA PUTERA \\ ZUNI BAROKAH* \\ Fakultas Ekonomika dan Bisnis Universitas Gadjah Mada
}

\begin{abstract}
This study investigates the impact of foreign currency volatility on companies' stocks returns and cash flow. Based on the analysis of 184 companies during January 2011 - December 2015, we find significant associations between foreign currency volatilities (REER) and companies' stock returns. Further, we also find significant associations between foreign currency volatilities (REER, USD, JPY, EUR) and companies' quarterly cash flows. However, further inspection by using annual financial statements to replace quarterly cash flows reveals that only REER has a significant association with annual cash flows. Although the difference findings could be due to a smaller number of samples included in the model using annual cashflows $(n=920)$ which is much smaller than the model incorporating quarterly cashflows $(n=3,660)$, the findings may also indicate that the effect of foreign currency volatility is more pronounced to the more timely financial statements and is dissipated overtime in the annual financial statements. Overall, the findings are consistent with previous studies of Booth \& Rotenberg (1990), Bartram (2008), and Atanasov \& Nitschka (2015) which suggest that corporate cash flows are subject to foreign currency volatilities and companies' future cash flow might be disturbed due to unexpected exchange rates changes.
\end{abstract}

Keywords: foreign currency volatility; REER; stock returns, cash flows, quarterly cash flows;

Intisari: Studi ini menyelidiki dampak dari volatilitas mata uang asing pada pengembalian saham perusahaan dan arus kas. Berdasarkan analisis 184 perusahaan selama Januari 2011 - Desember 2015, kami menemukan hubungan yang signifikan antara volatilitas mata uang asing (REER) dan pengembalian saham perusahaan. Selanjutnya, kami juga menemukan hubungan yang signifikan antara volatilitas mata uang asing (REER, USD, JPY, EUR) dan arus kas kuartalan perusahaan. Namun, pemeriksaan lebih lanjut dengan menggunakan laporan keuangan tahunan untuk menggantikan arus kas kuartalan mengungkapkan bahwa hanya REER yang memiliki

* Corresponding author: zuni.b@ugm.ac.id 
hubungan signifikan dengan arus kas tahunan. Meskipun temuan perbedaan bisa disebabkan oleh sejumlah kecil sampel yang termasuk dalam model menggunakan arus kas tahunan $(n=920)$ yang jauh lebih kecil daripada model yang menggabungkan arus kas kuartalan $(n=3.660)$, temuan juga dapat menunjukkan bahwa efek dari volatilitas mata uang asing lebih nyata pada laporan keuangan yang lebih tepat waktu. Secara keseluruhan, temuan konsisten dengan studi sebelumnya Booth \& Rotenberg (1990), Bartram (2008), dan Atanasov \& Nitschka (2015) yang menunjukkan bahwa arus kas perusahaan tunduk pada volatilitas mata uang asing dan arus kas masa depan perusahaan mungkin terganggu karena perubahan nilai tukar yang tidak terduga.

Kata Kunci: volatilitas mata uang asing; REER; return saham, arus kas, arus kas kuartalan;

\section{Introduction}

This research investigates the relationship between foreign currency volatility to stock return and cash flows. The magnitude of foreign currency transactions keeps increasing due to the more integrated international market, such as the ASEAN Economic Community. This situation will result in an inevitable foreign currency risk (opportunity) to companies conducting the international transaction.

The relation of foreign currency exposure to multinational companies operation is significant, especially for companies that operate in more than two countries. There can be a direct and indirect problem to business. The direct problems arise when companies must translate currencies and the fluctuations on foreign currency rate may substantially alter material costs, whereas the indirect problems occur when a company is competing against foreign products while their national currency is in bullish trend which will affect the ability to sell goods in foreign countries in competitive prices (Kumar \& Joshi, 2014). It is inherent issues for companies that operate and are dependent to the value of foreign currency, which can affect revenue significantly and will eventually influence on how public perceive company's ability to manage their operation, hence, affect its stock value.

IAS 21 (para 28) mentions that "exchange differences arising on the settlement of monetary items or on translating monetary items at rates different from those at which they were translated on initial recognition during the period or in previous financial 
statements shall be recognized in profit or loss in the period in which they arise" and paragraph 39 stated that income and expenses along with other comprehensive income should be translated at the date of the transaction. The statement may indicate that foreign currency exchange will influence a company's value which can be measured through cash flow and stock return. The variables that affect foreign currency exposure to multinational companies' operation are its national economy, the more open economy is, and the stronger is the relationship between return on the stock markets and exchange rates (Friberg and Nydahl, 1999). Pierdzioch and Kiyzs (2010) also find evidence of a co-integration relation between national exchange rate exposure and the industry composition of a country's import.

There is a transaction exposure that can affect companies' monetary transaction, which meant for profits but could be obstructed by the fluctuation of foreign currency. This kind of problem involving derivatives such as currencies can be a significant problem for a business transaction, if a company conduct business in payables and need to pay in the future where its main currency depreciates, it can suffer from a big loss. And there are cases where companies get lower sales in units when their home currency's rate appreciate (Ma and Kao, 1990) - hence, exposure on company's revenue and debt. This can be an adverse impact for the company's stock value because this situation can be perceived as the declining trend of a company's performance by investors. There is also translation exposure due to the translation of books of accounts into home currency. And the most important is economic exposure which can directly impact the value of the firm, which is the function of operating cash flows and the asset it possesses.

Exchange rate impact is more pronounced for firms that use foreign currency in their operations, and exposure is high for importing and exporting firms. For exporting (importing) firms devaluation of the domestic currency enlarges (diminishes) the profits and stock returns in domestic currency (Pritamani, Shome, and Singal, 2004). Exposed multinational companies may also have problems regarding their cash flows, as it can disrupt their operating cash flows and debt payment. As the capital market and trade becomes more integrated and open, the risk of foreign currency exposure 
due to exchange rate volatility also become more critical over the years. Also, $\mathrm{He}, \mathrm{Ng}$ and $\mathrm{Wu}$ (1997) found that Japanese multinationals' stock returns are positively correlated with contemporaneous exchange rates. Cash flow exposure is also relevant to be analyzed as it is more impacted than equity prices, it also emphasized in theoretical literature in academic research, and those reasons were: tax reasons, bankruptcy, investment decision, managerial performance or compensation purposes (Bartram, 2007). But looking at prior studies that show weak evidence of exposure in U.S. stocks such as exchange rate exposure is rather nonlinear than linear for US multinationals which could explain the scant evidence of foreign currency. There are still few studies that analyze the exposure of foreign currency in the company's cash flow volatility. From these issues, this research aims to find out how the relationship between foreign currency volatility affects Indonesian non-financial multinationals cash flow and stock return.

Accordingly, there are indications on the effect of foreign currency volatility which causes the foreign currency exposure - has a significant relationship to companies' cash flow volatility and stock return in Indonesian non-financial companies. For example, operating exposure has links to various factors such as competitiveness, entry barriers, etc. subjective and interpretation of different experts may be different causing firms' value to fluctuate. Some studies stated that foreign currency rate is truly unexpected, and the exchange rate is not priced in the Indonesian stock market and moreover, foreign currency exposed equities have on average lower returns. There is a need to research how significant foreign currency exposure is affecting the stock's value in Indonesian non-financial companies, to what extent public consider foreign currency exposure risk is essential to non-financial companies. Prior research stated above have shown that there are relationships between foreign currency to stock returns and cash flows.

This research aims to analyze to what extent foreign currency volatility affects cash flows and stock returns of Indonesia listed companies, by focusing on these research questions:

a. What is the impact of foreign currency volatility on companies' cash flows? 
b. What is the impact of foreign currency volatility to companies' stock return?

This research focuses in estimating foreign currency volatility both from a stock return to assess exposure from investor's point of view, and cash flow to assess the exposure more to corporate's point of view inspired by the study of Bartram (2007). Thus, it is essential to test whether there is a negative or positive impact of foreign currency volatility to companies' stock return and cash flow and also to provide insights on the risk of foreign currency exposed companies.

This study aims to provide contributions in some ways. First, it informs companies from different industries on how and which currency will affect Indonesian capital market the most, to enable them to manage their risks from foreign currency exposure, hence, giving them a competitive advantage in the international market. Further, this research will help investors to understand the relationship of foreign currency exposure to stock's return and cash flow and provide more understanding that will lead to a better decision in investing. Furthermore, this research provides empirical evidence of foreign currency volatility to companies' cash flows and stock returns. The finding shows that foreign currency volatility is associated with companies' cash flows. This proves that companies' cash flows are subject to foreign currency volatilities and its future growth might be disturbed from unexpected changes.

\section{Literature Review and Hypothesis Development}

This section discusses theoretical lenses that are used in this study, i.e., the efficient market hypothesis. Based on the theory, this study proposes two nondirectional hypotheses.

\subsection{The Efficient Market Hypothesis}

An efficient capital market is a market where security prices fluctuate according to all new information available, meaning that the current prices of securities reflect all information available in the market (Reilly \& Brown, 2012). In an efficient capital market, where securities adjust rapidly to the infusion of new information can be 
referred to as an informationally efficient market. The basic assumptions underlying efficient market are: (1) a large number of profit-maximizing participants analyze and value securities independently for every individual, (2) new information regarding securities comes to the market in a random fashion, and (3) the buy and sell decisions of all those profit-maximizing investors causing security prices to adjust rapidly to reflect the effect of new information (Fama, 1970).

According to Fama (1970), market efficiency is classified into three categories. First is the weak form where all information containing past price data are fully reflected on the current prices. It states that the return on the market is independent and past rates of return do not affect future rates. Weak efficiency thus rejects technical analysis, which is the study of the stock's performance based on the past trends consistent with the random walk hypothesis. Second is the semi-strong form, where prices adjust to information that is publicly available to all market participants (i.e., dividend and earning announcements and political or economic events), it assumes that stocks adjust quickly to absorb new information and also incorporates the weak form hypothesis; thus it rejects fundamental analysis. As the current prices already take into consideration all the present available public information, fundamental analysis will not help to beat the market. The third is the strong form where prices adjust to all public and privileged information from public and private sources available to every market participants. In the strong form, securities will always equal to their fair and fundamental values, and any change in the fundamental value will be reflected immediately in the market price (Kumar \& Joshi, 2014).

The main attractiveness of the efficient market hypothesis relies on the fact that it is built upon economic theory, specifically "random walk" that is the EMH is related to "the random walk", where price series have subsequent price changes which are random departures from previous prices. Minjina \& Brezeanu (2013) found that the Romanian stock market as a market in a developing country is having a trend towards confirming the weak form of the efficient markets hypothesis. Kelikume (2016) found empirical evidence that shows the Nigerian stock market also as a market in the developing country follows the random walk behavior and that is informationally 
efficient. That is to say, and stock prices actually possess all available information in the market.

\subsection{Foreign Currency Volatility}

Adler \& Dumas (1984) defined exposure as "The amounts of foreign currencies which represent the sensitivity of the future, real domestic-currency (market) value of any physical or financial asset to random variations in the future domestic purchasing powers of these foreign currencies, at some specific future date". Foreign currency exposure can also be broadly defined as exchange rate volatility risk that affects multinationals and large corporation, also small and medium-sized enterprises as well, even those that only operate in their home country. Papaioannou (2006:3) defined foreign currency risk as "the possible direct loss (as a result of an unhedged exposure) or indirect loss in the firm's cash flows, assets and liabilities, net profit and, in turn, its stock market value from an exchange rate move." Foreign currency exposure is divided into three types of risk caused by currency volatility (Papaioannou, 2006:4) The first risk is transaction exposure arises from the effect that exchange rate fluctuations have on a company's obligations to make or receive payments denominated in foreign currency in the future. This exposure has short-term to medium-term nature. The second risk, translation exposure arises from the effect of currency fluctuations on a company's consolidated financial statement, particularly for those that have foreign subsidiaries. This exposure has short-term to medium-term nature. The third risk, economic (or operating) exposure, is the lesser known from the previous two, but still has significant risk. Economic exposure rises from unexpected currency fluctuations of a company's future cash flows and market value and tends to have long-term nature. This exposure can have a substantial impact, as unexpected exchange rate changes can primarily affect the company's competitive position, even if the operation is domestic or internationally.

Currently, investment banks and market participants have significant volatility exposure with no acceptable method of hedging, but Krause (2000) explained that using realized volatility formula can provide a method for market participants to 
speculate on, or hedge against, changes in actual volatility (during the realized volatility period).

\subsection{Foreign Currency Volatility \& Stock Return (H1)}

Previous research (for example, $\mathrm{He}, \mathrm{Ng}$ and $\mathrm{Wu}, 1997$ ) found that both the market and currency risks are priced in the stock market, and they are time-varying. He et al. (1997) also found that 25 percent of 171 Japanese multinationals' stock returns are positively correlated with contemporaneous exchange rate changes. Further, highly-leveraged firms or firms that pay large dividends tend to have smaller exchange rate exposures, and smaller firms tend to hedge more than larger firms do. Furthermore, research by Korhonen (2015) found the existence of a co-integration relationship between effective exchange rates and national stock market indices and stated that the co-integration relationship affects exchange rate exposure.

Furthermore, another study (for example, Bacha et al., 2013) found significant exchange rate exposure from 158 firms in Malaysian listed firms, which is substantially higher than most countries, especially developed ones. Also USD as the most important source of exposure with 63 percent of sample firms exposed to foreign currency. Also states that from previous studies the U.S. and developed European markets have minimal impact of exchange rate exposure on firm value because they are among the least open economies. Proving that there is a possibility for a country not to be affected by foreign currency volatility considering its economic condition (economic exposure).

Concerning exporting and importing companies, a research done by Sangany (2015) stated that domestic currency depreciation is associated with more competitive local firms, leading to an increase in their exports which eventually raises their stock prices. This result is consistent with earlier research by Ma \& Kao (1990) which found that the currency appreciation for a dominant export country reduces the competitiveness of export markets and has a negative effect on the domestic stock market. A high currency value generates a favorable transaction exposure and creates excess demands for domestic stocks. 
The previous studies above show that the fluctuation of foreign currency will have a direct $\&$ indirect impact on a company's stock return through the transaction exposure and economic exposure. In Indonesia which currently suffers from depreciating home currency to US Dollar since mid-2014 due to US Fed interest rate increase, Badan Pusat Statistik (BPS) Indonesia reported that although Japanese Yen fluctuates throughout the year but looking at it broadly, Indonesian home currency still weakens to Japanese Yen, and Rupiah also depreciates about $26 \%$ to Euro for the period of 2011-2015. Rupiah also suffers from depreciation to Chinese Yuan about $56 \%$ throughout 2011 to 2015 . This will affect firms' operations and performance because these major currencies are often used for exporting and importing transaction - hence will reflect on how the public perceive firms' value (stock price). This research aims to test whether the foreign currency volatility has a significant relationship to stock return or not. Previous studies show that the increase in foreign currency risk will unfavorably affect firms' stock price. Therefore $\mathrm{H} 1$ expects:

\section{H1: There is a significant relationship between foreign currency volatility and company's stock return.}

\subsection{Foreign Currency Volatility \& Cash Flows (H2)}

Bartram (2007) estimated foreign currency exposure of numerous US non-financial firms using corporate cash flows. The estimation of cash flows exposures in this paper represents a sensible alternative to the common analysis of stock price exposures. The paper found that the impact of exchange rate risk on stock prices and cash flows is similar and that a related set of economic factors determines these types of exposures in a way that is consistent with economic theory and anecdotal evidence. Companies' future cash flows can be disturbed caused by the existence of economic exposure, due to unexpected exchange rates changes which will distort the present value used for its expected future cash flow (Booth \& Rotenberg, 1990). The statement earlier is also consistent with Sahlian et al. (2013) who suggests that cash flow risk exists when the amounts of future cash flows which can affect companies' earnings to change. It could 
be a contractual cash flow associated with an existing asset and liability, or it may be emerging from a transaction that is expected to occur but is not yet hedged by any means or contracts. Another research from Bartram (2008) also found that firms with a foreign currency based activities such as importer and exporter firms, its corporate cash flows are subject to foreign currency rate risk and became an important corporate objective and activity to hedge.

The foreign currency volatility on the firm level would affect changes in operating cash flows. This also can affect the reductions in firms' value, as the company suffers constraints in its internal financing and choose to raise external funds which will increase its cost of capital. Atanasov \& Nitschka (2015) found over the sample period from Dec. 1983 to Dec. 2010, sensitivities to the market return's cashflow news are significantly related to average excess returns on foreign currency portfolios and can jointly rationalize the cross section of both stock and foreign currency returns. Wei and Starks (2013) found that firms with greater growth opportunities, higher default probabilities, and more unique products resulted in higher foreign currency exposure. This would affect how investors perceive firms' risk management. Also, cash flow can be used to directly measure companies' internal performance and how managers implement their decision making.

Based on the above arguments, it is predicted that foreign currency exposure has a significant relationship to cash flow. Therefore $\mathrm{H} 2$ expects:

H2 = There is a significant relationship between foreign currency volatility and the company's cash flow

\section{Research Method}

\subsection{Data}

The data was taken from Indonesian Stock Exchange (IDX) website, Yahoo Finance, Osiris database, and Pusat Kajian Pasar Modal Universitas Gadjah Mada. The financial companies were removed due to the complexity and variance in technical management analysis regarding the foreign currency volatility. The period used in this research will be from January 2011 to December 2015. Then, this research 
will take a sample of shares from non-financial companies in Indonesia Stock Exchange for the span of 5 years (January 2011 - December 2015) to measure the movement of stock price following the changes in home currency in Indonesia (Rupiah). The data for monthly and yearly stock information, such as end-of-period closing prices and return will be collected from the Indonesia Stock Exchange, Yahoo Finance, and Osiris database. With regard to the exchange rate, this study will use a daily nominal exchange rate of Rupiah (IDR) against the US Dollar (USD), Japanese Yen (JPY), and Euro for Europe area (EUR) provided in Bank Indonesia website and monthly REER broad index obtained from Bank for International Settlements website with the time span of 5 years during January 2011 to December 2015.

The population consists of all listed non-financial companies in Indonesia Stock Exchange (IDX), and the samples would be 184 companies from the total population would be used to test. The purposive sampling process follows these categories:

1. The companies that are still listed and not delisted in the period from 2011 to 2015.

2. Companies that have complete information on the stock return, no return (changes) would be still accepted.

3. Companies that are not included in the financial sector.

4. Stocks that are available to trade in the IDX

\subsection{Dependent Variable}

\section{Stock Return}

For stock returns, the monthly stock return will cover the period of January 2011 - December 2015, and calculated according to this equation (Jogiyanto, 2015):

$\mathrm{R}_{\mathrm{it}} \quad=\left(\mathrm{P}_{\mathrm{t}}-\mathrm{P}_{\mathrm{t}-1}\right) / \mathrm{P}_{\mathrm{t}-1}$

Where:

$\mathrm{R}_{\mathrm{it}}=$ Stock Return from companies listed in Indonesia Stock Exchange, excluding the financial sector. 
$\mathrm{P}_{\mathrm{t}}=$ Stock price in period $\mathrm{t}$ (end of the month)

$\mathrm{P}_{\mathrm{t}-1}=$ Stock price in period $\mathrm{t}-1$ (end of the prior month)

\section{Quarterly Cash Flow}

Quarter Cash Flow is used as a proxy to analyze the volatility of foreign currency to the changes in cash flows throughout the year, from 2011 to 2015. It will be calculated using this formula to include it in the model:

$\mathrm{CFQ}=\mathrm{LN}\left(\mathrm{CFQ}_{\mathrm{i}, \mathrm{t}}\right)$

Where:

$\mathrm{CFQ}_{\mathrm{i}, \mathrm{t}}=$ Quarter Statement of Cash Flow for Company i, which is the net quarterly cash flow reported in the quarterly financial statement.

LN $\quad=$ Log Natural

\section{Annual Cash Flow}

Annual net Cash Flow is used as an audited form to confirm the finding from Quarter net Cash flow from 2011 to 2015.

$\mathrm{CFA}_{\mathrm{i}, \mathrm{t}} \quad=\mathrm{LN}\left(\mathrm{CFA}_{\mathrm{i}, \mathrm{t}}\right)$

Where:

$\mathrm{CFA}_{\mathrm{i}, \mathrm{t}}=$ Annual Statement of Cash Flow for Company i, which is the net cash flow reported in the financial statement for the year ending $31^{\text {st }}$ December.

LN $=$ Log Natural 


\subsection{Independent Variables}

The independent variables employed in this study are market return, foreign currency data of Nominal Exchange Rate and Real Effective Exchange Rate (REER) of; USD, JPY, and EUR as its proxies. The nominal exchange rate is used to consider the impact in translation and transaction exposure resulting from the overseas transaction and translating foreign currency into home currency.

REER is used to consider any changes in international price or cost competition and allocate incentives between tradable and non-tradable goods. REER takes into account any changes in relative prices of a currency by comparing the relative trade balance of a country's currency against each country within the index. This variable is used to better understand the individual country's currency value relative to the other major currencies in the index.

The measurement of exchange rate volatility involves three steps:

1. Apply this equation to get the average currency rate of the day (Sulistyandari, 2011).

$$
\overline{M_{t}}=\frac{\text { (buying rate }+ \text { selling rate) }}{2}
$$

2. Measure the percentage of changes to get daily volatility of the nominal exchange rate.

$$
\mathrm{C}_{\mathrm{t}}=\ln \left(\overline{M_{t}} / \overline{M_{t-1}}\right)
$$

Where:

$\mathrm{C}_{\mathrm{t}}=$ changes is currency rate

$\ln =$ Natural Log

$\overline{M_{t}}=$ average of mark-to-market price at trading period $\mathrm{t}$

$\mathrm{M}_{\mathrm{t}-1}=$ average of mark-to-market price one period prior to $\mathrm{M}_{\mathrm{t}}$

3. Measure the volatility by using realized (historical) volatility formula.

$$
\mathrm{RV}=\sqrt{\frac{250}{n}} \sum_{t=1}^{n}\left(C_{t}-\bar{C}\right)^{2}
$$


Where:

$\mathrm{RV}=$ realized volatility

$\bar{C}=$ mean of $\mathrm{C}_{\mathrm{t}}$ for a year

$n=$ number of trading periods within the realized volatility period observed.

Realized volatility is the square root of the squared of difference between changes in currency rate and its mean multiplied to a constant to bring the measure of volatility to an annualized scale concerning the observed period (Krause, 2000). The number 250 is used as a constant by taking holiday dates and non-trade days into account for the year, regardless of different holiday calendar for countries used in the research. "The use of RV as a proxy for the unobservable volatility simplifies the estimation considerably. Filtering procedures are no longer required, and the model can be estimated directly using the observed RV, as obtained from high-frequency data" (Corsi, F. et al., 2012).

$\mathrm{USD}_{\mathrm{t}}, \mathrm{JPY}_{\mathrm{t}}, \mathrm{EUR}_{\mathrm{t}}=$ Realized volatility of nominal exchange rate of US Dollar (USD), Japanese Yen (JPY), and Euro for Europe area (EUR) to Indonesian Rupiah (IDR). It was measured by first calculating the average currency rate to get a single rate from buying and selling rate for the day. Then, calculating the changes in the daily exchange rate to quantify the daily volatility. After that, applying the realized volatility formula for the different time frame of monthly, quarterly, and annually to capture different volatilities to be used in the regression.

$R E E R_{\mathrm{IDt}}=$ Realized volatility of Realized Effective Exchange Rate (REER) of Indonesia. It will be measured by first calculating its monthly changes throughout five years for 2011 to 2015 and then take the mean for each year with the intention to capture the difference amount of volatilities within the time frame observed. After that applying the realized volatility formula for monthly, quarterly, and annual time frame. This can be done by changing the time observed in the formula. 


\subsection{Control Variables}

This study also employs control variable such as Interest-bearing liability and total asset. This study will focus on non-financial listed companies in Indonesia Stock Exchange for the period of 2011-2015. In this study, these data were obtained from the Osiris database.

\section{Interest-bearing Liability}

Demirgüç-Kunt and Levine (1996) stated that in developing markets, stock markets and banks are not substituted sources of corporate finance; stock market development tends to increase the quantity of bank loans (proxy: interest-bearing liabilities). Following the Trade-Off Theory, which stated that by financing its capital using debt reduces taxes, and allows more firm to generate more earnings before interest and tax (EBIT), this theory holds the assumption that stock price would be maximized at $100 \%$ debt. Even though in the real world, firms tend to target lower debt ratio to decrease inherent bankruptcy risks that lie within financing in debt (Brigham \& Houston, 2013).

This study assumes that the higher interest-bearing liabilities in company's capital structure, it will be reflected on higher foreign currency risks which affect cash flows (proxy: net annual \& quarter cash flow) and company's value (stock return) following changes in foreign currency.

\section{Market Return}

The data for market return will be obtained from IHSG (Index Harga Saham Gabungan) index. Data obtained from closing share price in each month from January 2011 to December 2015.

Daily market return will be calculated based on the equation below (Nikita \& Soekarno, 2012):

$$
\mathrm{R}_{\mathrm{mt}}=\mathrm{LN}\left(\mathrm{P}_{\mathrm{it}} / \mathrm{P}_{\mathrm{it}-1}\right)
$$


Where:

$\mathrm{R}_{\mathrm{mt}}=$ Market Return from listed companies in Indonesia Stock Exchange in the monthly term.

$\mathrm{P}_{\mathrm{it}}=$ index daily closing price at period $\mathrm{t}$

$\mathrm{LN}=$ natural $\log$

\section{Total Asset}

The total asset was used as a proxy to measure whether a company's size affects how investor assesses and value the company. The total asset value will also vary following the changes in foreign currency following the belief that the greater asset the company means that it would have more flexibility and access to funding sources to obtain debt, which will be used to enhance its financial performance (Widjaja and Kasenda, 2008). To measure this variable, size of a company is measured as log natural of total assets.

\subsection{Hypotheses Testing}

Panel Data is used in this study due to its samples characteristics that have both time series and cross-sectional data. Panel data contains an observation of various phenomena involving measurements over time. This research will use regression to test the relationship between foreign currency exposure to stock return and cash flow, following Suciwati (2002).

\section{Statistical model for hypothesis 1}

$\mathrm{R}_{\mathrm{it}}=\alpha_{\mathrm{i}}+\beta_{1 \mathrm{iUSDt}}+\beta_{2 \mathrm{iJPYt}}+\beta_{3 \mathrm{iEURt}}+\beta_{4} R E E R_{\mathrm{IDt}}+\beta_{5 \mathrm{i}} \mathrm{R}_{\mathrm{mt}}+\mathrm{e}_{\mathrm{it}}$

\section{Statistical model for hypothesis 2}

$\mathrm{CFQ}_{\mathrm{i}}=\alpha_{\mathrm{i}}+\beta_{1 \mathrm{iUSDt}}+\beta_{2 \mathrm{iJPYt}}+\beta_{3 \mathrm{iEURt}}+\beta_{4 \mathrm{i}} R E E R_{\mathrm{IDt}}+\mathrm{e}_{\mathrm{t}}$

$\mathrm{CFA}_{\mathrm{i}}=\alpha_{\mathrm{i}}+\beta_{1 \mathrm{iUSDt}}+\beta_{2 \mathrm{iJPYt}}+\beta_{3 \mathrm{iEURt}}+\beta_{4 \mathrm{i}} R E E R_{\mathrm{IDt}}+\mathrm{e}_{\mathrm{it}}$

Where:

$$
\begin{array}{ll}
\alpha_{\mathrm{i}} & =\text { Intercept } \\
\beta 1_{\mathrm{i}} & =\text { Coefficient }
\end{array}
$$




$$
\begin{array}{ll}
\mathrm{e}_{\mathrm{it}} & =\text { Error Term } \\
\mathrm{CFA}_{\mathrm{i}} & =\text { Net Annual Cash Flow of company } \mathrm{i} \\
\mathrm{CFQ}_{\mathrm{i}} & =\text { Net Quarter Cash Flow of company } \mathrm{i} \\
\mathrm{R}_{\mathrm{mt}} & =\text { Market Return index (IHSG) at period } \mathrm{t} \\
\mathrm{R}_{\mathrm{it}} & =\text { Stock Return for company } \mathrm{i} \text { at period } \mathrm{t}
\end{array}
$$

Statistical models above will be used in the regression and then applied for data analysis to obtain the study result, which was done using Eviews 9. From the model above, it is shown that this study will go through three stages of statistical tests. The first stage would be examining the effect of foreign currency volatility and real effective exchange rate (REER) on stock returns $\left(R_{i t}\right)$ to be controlled by variables such as market return $\left(\mathrm{R}_{\mathrm{mt}}\right)$, Total Asset (Size), and interest-bearing liability. The second statistical test would be to examine the effect of foreign currency volatility and real effective exchange rate (REER) on Net Quarter Cash Flow (CFQ) to be controlled by Total Asset (Size), and interest-bearing liability. And the third statistical test would examine foreign currency volatility and real effective exchange rate (REER) on Net Annual Cash Flow (CFA) also to be controlled by Total Asset (Size) and interestbearing liability.

The selection of a statistical model will influence the output results from the regression. The selection of the right model will significantly affect the interaction of each independent variables and dependent variables in the model. This study employ panel data as it included cross-section and time-series data, three techniques can be used to estimate panel data regression: OLS approach (common effect), Fixed Effect model, and Random Effect model.

In determining which model suitable for which regression model in the hypotheses proposed, the Chow test would be performed. Chow test is widely used to compare the common effect of the fixed effect model. After that, Hausman test would be performed to compare the fixed effect and random effect model, and if the results are not consistent Lagrange-multiplier test should be performed to compare the random effect and common effect to obtain which method is the most appropriate. 


\subsection{Data Preparation}

Classical statistic test is mandatory to be performed to fulfill the assumption of BLUE (Best, Linear, Unbiased Estimator) criteria for regression analysis. This study employed Normality, Autocorrelation, Heteroscedasticity, and Multicollinearity tests.) This section discusses the findings obtained from the statistical analysis that had been performed. The process involved is sampling process following a purposive sampling method, samples were collected from Osiris database, Bloomberg database provided by Pusat Kajian Pasar Modal Universitas Gadjah Mada, and Bank Indonesia official website. These samples are monthly stock return, volatility of foreign currencies (USD, JPY, EUR) to Indonesian Rupiah, volatility of Indonesia's REER, also quarter and annual cash flows. Also, there were control variables employed in this study, such as stock trade volume, market return, total asset, and interest-bearing liability. This chapter will discuss the statistical descriptive and hypothesis testing in which the data would be tested using Eviews 9 software.

\section{Results and Discussions}

The study takes samples from Indonesian listed companies in the non-financial sector. The financial sector is excluded due to its inherent complexities in financial estimation for five years (2011-2015). For this study, the available sample taken from the population are 184 companies for the first model and 183 companies for the second and third model. Other companies are excluded because they were not able to fulfill the purposive sampling criteria, such as the stock was rarely traded in the exchange, incomplete financial data during the period of 2011-2015.

\subsection{Descriptive Statistics}

The descriptive statistics explains the characteristics of the data used in this study, by taking note that the sample taken employs a purposive sampling method. Samples used in this study were taken from non-financial listed companies in Indonesia Stock Exchange during 2011-2015. The following table shows the output of descriptive statistics of each variable from each model used in this study, which includes some 
observation, minimum and maximum value, mean, and standard deviation. According to the output obtained from table 4.3, information concerning descriptive statistics from both dependent and independent variables can be acquired.

The first dependent variable that was tested on hypotheses 1 is stock return (r). The descriptive statistics of ( $r$ ) shows that the sample has a mean of 0.0098, with the minimum value of -0.91 , the maximum value of 12.33 and standard deviation of 0.20289 from a total of 184 companies and 11,040 observations for the monthly timeframe of 2011-2015. Independent variables employed for the first model were proxied using USD with a mean of 0.0527 , minimum value of 0.01 , and a maximum value of 0.15 ; JPY has a mean of 0.0905 , minimum value of 0.04 , and a maximum value of 0.17; EUR has a mean value of 0.0850 , minimum value of 0.04 , and maximum value of 0.17 and to take into account changes in relative prices of Indonesia's currency by comparing its relative balance against other countries' currency in the basket, provided in an index called REER with a mean of 0.03690 , minimum value of 0.00 , and maximum value of 0.17 . There were also control variables employed in this model. The control variables are market return (rM) and TradeVolume. Market return (rM) has a mean value of 0.0029 , minimum value of 0.03 , and maximum value of -0.03 . The second control variable is Trade Volume, with a mean value of 6.9876 , the minimum value of 0.00 , and the maximum value of 10.38

Table 1

Descriptive Statistics (Stock Return Model) $(n=11,040)$

\begin{tabular}{|l|c|c|c|c|}
\hline Variable & Mean & Standard Deviation & Minimum & Maximum \\
\hline Stock Return & 0.0098 & 0.20289 & -0.91 & 12.33 \\
\hline USD & 0.0527 & 0.03056 & 0.01 & 0.15 \\
\hline JPY & 0.0905 & 0.03055 & 0.04 & 0.17 \\
\hline EUR & 0.0850 & 0.02524 & 0.04 & 0.17 \\
\hline REER & 0.0369 & 0.03442 & 0.00 & 0.17 \\
\hline Market Return & 0.0029 & 0.01138 & -0.03 & -0.03 \\
\hline TradeVolume & 6.9876 & 1.44478 & 0.00 & 10.38 \\
\hline
\end{tabular}


The second dependent variable is quarter cash flows which show a mean of 8.6515, with a minimum value of 0.00 , the maximum value of 14.07 , and standard deviation of 2.19588 from a total of 183 companies in quarterly (3 months) timeframe during 2011-2015. Independent variables employed in this model were proxied using: USD with a mean value of 0.0559 , minimum value of 0.01 , and maximum value of 0.11 ; JPY with a mean value of 0.0800 , minimum value of 0.00 , and maximum value of 0.15; EUR has a mean value of 0.0759 , minimum value of 0.00 , and maximum value of 0.13 ; also REER with a mean value of 0.0413 , minimum value of 0.01 , and maximum value of 0.13 . Along with the control variable of Size proxied by total asset (Asset_transformed) with a mean value of 6.3122, the minimum value of 3.87 , and the maximum value of 8.41 ; next is control variable of Interest-Bearing Liability (IntBearLia_transformed) with a mean value of 4.7278 , minimum value of 0.00 , and maximum value of 7.63 .

Table 2

Descriptive Statistics (CFQ model) $(\mathrm{n}=3,660)$

\begin{tabular}{|l|l|l|l|l|}
\hline Variables & Mean & SD & Min. & Max. \\
\hline Quarterly Cash Flows & 8.6515 & 2.19588 & 0.00 & 14.07 \\
\hline USD & 0.0559 & 0.02416 & 0.01 & 0.11 \\
\hline JPY & 0.0800 & 0.04093 & 0.00 & 0.15 \\
\hline EUR & 0.0759 & 0.03653 & 0.00 & 0.13 \\
\hline REER & 0.0413 & 0.02898 & 0.01 & 0.13 \\
\hline Asset & 6.3122 & 0.79459 & 3.87 & 8.41 \\
\hline Liabilities & 4.7278 & 1.90391 & 0.00 & 7.63 \\
\hline
\end{tabular}

The third dependent variable is annual cash flows with a mean of 15.0905, the minimum value of 7.56, the maximum value of 19.99, and standard deviation of 2.15326 from a total of 183 companies in yearly timeframe during 2011-2015. Independent variables employed in this model were proxied using: USD with a mean value of 0.0559 , minimum value of 0.01 , and maximum value of 0.11 ; JPY with a mean value of 0.0800 , minimum value of 0.00 , and maximum value of 0.15 ; EUR 
with a mean value of 0.0759 , minimum value of 0.00 , and maximum value of 0.13 . Also, the last independent variable is REER, with a mean value of 0.0413 , the minimum value of 0.01 , and the maximum value of .13 . Along with the control variable of Size proxied by Asset with a mean value of 6.3122, next is control variable of TradeVolume with a mean value of 4.7278 .

Table 3

Descriptive Statistics (CFA model) $(\mathrm{n}=920)$

\begin{tabular}{|c|c|c|c|c|}
\hline Variables & Mean & SD & Minimum & Maximum \\
\hline Annual Cash Flows & 15.0905 & 2.15326 & 7.56 & 19.99 \\
\hline USD & 0.0598 & 0.00908 & 0.05 & 0.07 \\
\hline JPY & 0.0938 & 0.01366 & 0.08 & 0.12 \\
\hline EUR & 0.0873 & 0.01164 & 0.08 & 0.11 \\
\hline REER & 0.0443 & 0.02338 & 0.02 & 0.08 \\
\hline Asset & 9.3461 & 0.80350 & 6.95 & 11.39 \\
\hline Liabilities & 7.7708 & 2.29638 & 0.00 & 10.61 \\
\hline
\end{tabular}

The results of the descriptive statistics above indicate that the sample used in this study consists of different types of companies. Such variations can be seen in terms of amount in the total asset, its capital such as interest-bearing liability, and how active the stock is traded in trading volume. Also, every variable has its mean value of the standard deviation. A moderate height of std dev means that the minimum and maximum values of the variables have a range that is not too far away. The normal range of data suggests that the variability of the data is also moderate. The relationship between stock returns, cash flows, foreign currencies volatility and its controlling variable size effect will be discussed further in the following part.

\subsection{Data Preparation}

Normality

After performing Kolmogorov-Smirnov approach by referring to significant value $\mathrm{Z}<0.05$ which explains that the data were not normally but referring from the result 
obtained by looking at the graph shape it is normally distributed (bell-shaped). And this research hold on the Central Limit Theorem, due to the sample size constraint, and this research employs more than 50 companies as a sample which approves the assumption in theory.

\section{Autocorrelation}

The Durbin-Watson test conducted using Eviews 9 software resulted in 1.498375 $\mathrm{dw}$ value after running Model 1. After running model 2, the Durbin-Watson value of 1.822313 is obtained. The Durbin-Watson value for Model 3 is 1.19098 . It is safe to say that three models employed in this study are safe from the presence of autocorrelation due to its d value still in between the range of +2 and -2 . The explicit test of finding out autocorrelation in model 1 was omitted for this model due to the amount of observation employed in this study, and because linear autocorrelations in asset returns are often insignificant, except for smaller intraday time frame (e.g., 20 minutes) where microstructure effects are considered (Cont, 2007). Moreover, even if autocorrelation exists within the model, the estimator is still linear and unbiased (Gujarati, 2012).

\section{Heteroscedasticity}

Tabachnick and Fidell (2007) explain the residuals (the difference between obtained DV and the predicted DV scores) and the variance of the residuals should be the same for all predicted scores (homoscedasticity). If this is true, the assumption is met, and the scatter plot takes the (approximate) shape of a rectangular; scores will be concentrated around the 0 points and distributed in a rectangular pattern. Simply put, scores will be randomly scattered about a horizontal line. However, classical econometric assumes that heteroscedastic phenomenon as a nuisance in econometric modeling. But in time series econometrics' point of view, the data can be modeled following its original pattern in the observation period. The pattern is stylized facts, especially volatility clustering which explain data characteristics that shows clustering in high and low variance (Simarmata \& Hartono, 2016). 
After observing the scatterplot obtained, Model 1 is already homoscedastic even though most of it are flocking around 0. It is still safe due to no obvious pattern are existent. Model 2 and Model 3 also satisfy the homoscedastic requirements as its scatterplot is already scattered with no obvious pattern throughout its data. Therefore, after considering prior literature and looking at the scatter plot pattern, this model can be said as free from heteroscedasticity.

\section{Multicollinearity}

All independent variables VIF (Variance Inflation Factor) values are below 5 and by observing the Tolerance value with the threshold of 1 for multicollinearity symptom. The result obtained shows there is no symptom of multicollinearity among independent variables from those three models.

\subsection{Hypothesis 1}

This study employs a panel data regression which means a combination of crosssection and time-series data, where the cross-section units were measured across the particular period. The total observation units would be calculated as cross-section data (n) $x$ time-series data (t). The balanced panel is used when the amount of period for every cross-section units are the same. Otherwise, the unbalanced panel will be used. Prior to the estimation of the regression model, there is a need to determine which statistical approach to be used for hypothesis testing to obtain the most effective result. Therefore we performed the Chow Test, Haussman Test, and Lagrange Multiplier Test.

Chow test is carried out to compare between Pooled Least Square method $\left(\mathrm{H}_{0}\right)$ and Fixed Effect method $\left(\mathrm{H}_{1}\right)$. Referring to the Cross-section Chi-square, if it is $<0.05$ then it means that fixed effect is the appropriate approach, however, if it is $>0.05$, it means the common effect is to be used rather than fixed effect. 
Table 4

Chow test Result for Model 1

\begin{tabular}{|l|c|c|c|}
\hline Effect Test & Statistic & d.f. & Prob. \\
\hline Cross-section F & 1.434987 & $(183,10850)$ & 0.0001 \\
\hline Cross-Section Chi-square & 264.018904 & 183 & 0.0001 \\
\hline
\end{tabular}

According to the result obtained, the table above shows that both $\mathrm{F}$ and Chi-square test is significant with $\mathrm{P}$-value of 0.0001 which is less than 0.05 . Therefore the $\mathrm{H}_{0}$ is rejected, and $\mathrm{H}_{1}$ is accepted which suggests for this model fixed effect is more appropriate than common effect. Subsequently, Haussman Test is performed to compare the fixed effect and random effect.

Table 5

Haussman test Result for Model 1

\begin{tabular}{|l|c|c|c|}
\hline Test Summary & Chi-Sq. Statistic & Chi-Sq. d.f. & Prob. \\
\hline Cross-section random & 0.0000 & 6 & 1.0000 \\
\hline
\end{tabular}

Referring to its $\mathrm{P}$ value, if $\mathrm{P}<0.05$ then the analysis should use a fixed effect model $\left(\mathrm{H}_{1}\right)$ and otherwise, the random effect will be used $\left(\mathrm{H}_{0}\right)$. According to the test result above, with P-value $>0.05$ suggesting that random effect is a better fit. To continue further with choosing a statistical approach for panel data, the Lagrange Multiplier test is performed to choose between random effect and common effect. The test was performed using the Breusch Pagan method and will be interpreted by looking at its Cross-section $\mathrm{P}$ value. If it is $<0.05$ the appropriate method would be a Random effect. If it is $>0.05$, common effect should be chosen as the appropriate method 
Table 6

Lagrange-Multiplier Test Result for Model 1

\begin{tabular}{|l|c|c|c|}
\hline Effect Test & Cross-section & $\begin{array}{c}\text { Test Hypothesis } \\
\text { Time }\end{array}$ & Both \\
\hline Breusch-Pagan & 12.49833 & 1347.236 & 1359.734 \\
\hline & $(0.0004)$ & $(0.0000)$ & $(0.0000)$ \\
\hline
\end{tabular}

According to the result obtained, the Breusch-Pagan Cross-section P-value is below 0.05 . This test, therefore, determined the appropriate method for model 1 is the Random Effect. To conclude the three tests performed (Chow test, Haussman test, Lagrange-Multiplier test), it is decided that the Random Effect method is used to estimate statistical model 1.

Table 7

The Result of Model 1 for Hypothesis 1

\begin{tabular}{|l|c|c|c|c|}
\hline \multicolumn{5}{|c|}{ Dependent variable: $\mathbf{r}(\mathbf{n}=\mathbf{1 1 , 0 4 0})$} \\
\hline \multicolumn{1}{|c|}{ Variables } & Coefficient & $\begin{array}{c}\text { Standard } \\
\text { Error }\end{array}$ & t-statistic & $\begin{array}{c}\text { Probability } \\
\text { value }\end{array}$ \\
\hline C & -0.008567 & 0.013242 & -0.6469671 & 0.5177 \\
\hline USD & 0.109539 & 0.095426 & 1.147905 & 0.2510 \\
\hline JPY & 0.052702 & 0.070612 & 0.746352 & 0.4555 \\
\hline EUR & $\mathbf{- 0 . 5 9 2 1 2 2}$ & $\mathbf{0 . 1 0 8 1 0 8}$ & $\mathbf{- 5 . 4 7 7 1 3 8}$ & $\mathbf{0 . 0 0 0 0}$ \\
\hline REER & $\mathbf{- 0 . 1 2 1 9 4 1}$ & $\mathbf{0 . 0 6 2 4 4 0}$ & $\mathbf{- 1 . 9 5 2 9 2 9}$ & $\mathbf{0 . 0 5 0 9}$ \\
\hline RM & $\mathbf{- 0 . 8 7 4 5 9 1}$ & $\mathbf{0 . 1 7 5 7 2 4}$ & $\mathbf{- 4 . 9 7 7 0 7 8}$ & $\mathbf{0 . 0 0 0 0}$ \\
\hline TRADEVOL & $\mathbf{0 . 0 0 9 3 3 8}$ & $\mathbf{0 . 0 0 1 4 5 7}$ & $\mathbf{6 . 4 0 8 3 1 9}$ & $\mathbf{0 . 0 0 0 0}$ \\
\hline Adj. R-squared & & & & 0.010441 \\
\hline Durbin-Watson stat & & & & 1.505729 \\
\hline Prob. (F-statistic) & & & & 0.000000 \\
\hline
\end{tabular}

After the regression test was performed using a random effect method, it is concluded that by looking at the Prob (F-statistic) value which is 0.000000 , obviously lower than 0.05 which means every independent variables and control variable (Market Return and TRADEVOL) affect the dependent variable, which is stock return (r) in $95 \%$ confidence level. The result obtained from this model is not fully supporting $\mathrm{H}_{1}$ as not all foreign currency shows a significant relationship to the 
dependent, particularly USD and JPY which are not significant (p-values of 0.2510 and 0.4555 respectively). However, Table 7 shows that Euro and REER have negative and significant associations with stock return movement with the coefficients of 0.592122 and -0.121941 for Euro and REER, respectively. As for control variables, both show significant results (p-value of 0.0000). However, these two control variables have different directions in affecting the stock return. Market return (IHSG) affects stock return volatility negatively with the coefficient of -0.874591 ; whereas TradeVol (Trade Volume) has a coefficient of 0.009338.

The findings from this model are consistent with the efficient market hypothesis, where security prices would fluctuate according to all new information available. To note that the control variable employed such as TradeVol or trading volume and RM or market return, which are available freely in various sources, affect the dependent significantly. However it is essential to understand how well this model can explain the association between dependent and independent variables by looking at its $\mathrm{R}$ square, the bigger the $\mathrm{R}$ square would mean the better the model can estimate a particular phenomenon. Model 1 shows that the $\mathrm{R}$ square is 0.01097 , which is relatively low suggesting that there are some potentially omitted variables in the model.

\subsection{Hypothesis 2}

$\mathrm{H} 2$ examine the effect of foreign currency volatility on the companies' cash flows, by using quarterly cash flow as the dependent variable. Chow test is carried out to compare between Pooled Least Square method $\left(\mathrm{H}_{0}\right)$ and Fixed Effect method $\left(\mathrm{H}_{1}\right)$. Referring to the Cross-section Chi-square, if it is $<0.05$ then it means that fixed effect is the appropriate approach, however, if it is $>0.05$, it means the common effect is to be used rather than fixed effect. Referring to the result obtained, the Chi-square is < 0.05 . Therefore, the test suggests the use of the fixed-effect method. 
Table 8

Chow test Result for Model 2

\begin{tabular}{|l|c|c|c|}
\hline Effect Test & Statistic & d.f. & Prob. \\
\hline Cross-section F & 9.035840 & $(182,3457)$ & 0.0000 \\
\hline Cross-Section Chi-square & 1418.796892 & 182 & 0.0000 \\
\hline
\end{tabular}

The latter test would be Haussman test to compare between fixed effect and random effect.

Table 9

Haussman test Result for Model 2

\begin{tabular}{|l|c|c|c|}
\hline Test Summary & Chi-Sq. Statistic & Chi-Sq. d.f. & Prob. \\
\hline Cross-section random & 21.743389 & 6 & 0.0013 \\
\hline
\end{tabular}

After Haussman test was performed, with value $<0.05$ it is concluded that the method to be used for this model is fixed effect model. To conclude the tests performed (Chow test \& PHaussman test) both resulted in favor of fixed effect as the appropriate method to estimate statistical model 2.

As shown in Table 10, the Prob (F-statistic) is lower than $\alpha(0.000000<0.05)$ suggesting that independent variables in the model significantly affect the dependent variable, Quarterly Cash Flow (CFQ), with a confidence level of 95\%. Specifically, all foreign currencies (USD, JPY, EUR) are significant with $95 \%$ confidence interval to the dependent with coefficients of $2.362307,2.275163$, and -2.605698 respectively. Thus, $\mathrm{H}_{2}$ is supported. USD and JPY have a positive relationship with the dependent variable, whereas EUR and REER have a negative relationship with the dependent. As for the control variable, assets show negatively significant association with a coefficient of 1.494276 . 
Table 10

The Result of Model 2 for Hypothesis 2

\begin{tabular}{|l|c|c|c|c|}
\hline \multicolumn{5}{|c|}{ Dependent Variable: CFQ $(\mathbf{n = 3 , 6 6 0})$} \\
\hline Variable & Coefficient & $\begin{array}{c}\text { Standard } \\
\text { Error }\end{array}$ & t-statistic & Probability value \\
\hline C & -0.925457 & 0.723480 & -1.279175 & 0.2009 \\
\hline USD & $\mathbf{2 . 3 6 2 3 0 7}$ & $\mathbf{0 . 9 8 8 2 2 8}$ & $\mathbf{2 . 3 9 0 4 4 7}$ & $\mathbf{0 . 0 1 6 9}$ \\
\hline JPY & $\mathbf{2 . 2 7 5 1 6 3}$ & $\mathbf{0 . 8 2 8 3 9 9}$ & $\mathbf{2 . 7 4 6 4 5 7}$ & $\mathbf{0 . 0 0 6 1}$ \\
\hline EUR & $\mathbf{- 2 . 6 0 5 6 9 8}$ & $\mathbf{0 . 9 6 5 1 1 6}$ & $\mathbf{- 2 . 6 9 9 8 8 1}$ & $\mathbf{0 . 0 0 7 0}$ \\
\hline REER & $\mathbf{- 2 . 0 8 5 3 2 5}$ & $\mathbf{0 . 8 1 3 0 8 1}$ & $\mathbf{- 2 . 5 6 4 7 1 9}$ & $\mathbf{0 . 0 1 0 4}$ \\
\hline Assets & $\mathbf{1 . 4 9 4 2 7 6}$ & $\mathbf{0 . 1 1 8 1 3 1}$ & $\mathbf{1 2 . 6 4 9 2 9}$ & $\mathbf{0 . 0 0 0 0}$ \\
\hline Liabilities & 0.024610 & 0.020252 & 1.215213 & 0.2244 \\
\hline Adj. R-squared & & & & 0.703482 \\
\hline Durbin-Watson stat & & & & 1.822313 \\
\hline Prob (F-statistic) & & & & 0.000000 \\
\hline
\end{tabular}

\subsection{Additional Test of $\mathrm{H} 2$}

The previous test on $\mathrm{H}_{2}$ examines the effect of foreign currency volatility to companies' cash flows measured by using quarterly cash flow as the dependent variable. However, there is a question on whether the effect of foreign currency volatility still holds on annual cash flows. Therefore we estimate Model 3 to test the association between foreign currency volatility and annual cash flows as reported in the audited financial statement to confirm the findings from the earlier model.

We performed similar steps as in earlier models. First, Chow test is carried out to compare between Pooled Least Square method $\left(\mathrm{H}_{0}\right)$ and Fixed Effect method $\left(\mathrm{H}_{1}\right)$, second the Haussman test to compare Random Effect method $\left(\mathrm{H}_{0}\right)$ with Fixed Effect Method $\left(\mathrm{H}_{1}\right)$, and lastly Lagrange-multiplier test if necessary to compare Random Effect and Common Effect/Pooled Least Square.

Table 11

Chow test Result for Model 3

\begin{tabular}{|l|c|c|c|}
\hline \multicolumn{1}{|c|}{ Effect Test } & Statistic & d.f. & Prob. \\
\hline Cross-section F & 3.749293 & $(183,726)$ & 0.0000 \\
\hline Cross-Section Chi-square & 606.314912 & 182 & 0.0000 \\
\hline
\end{tabular}


From the result of the Chow test, the result shows that the Cross-section Chisquare is $<0.05$. Therefore fixed effect is considered as the appropriate model. Subsequently, we perform Haussman test to compare between fixed effect and random effect.

Table 12

Haussman test Result for Model 3

\begin{tabular}{|l|c|c|c|}
\hline Test Summary & Chi-Sq. Statistic & Chi-Sq. d.f. & Prob. \\
\hline Cross-section random & 0.0000 & 6 & 1.0000 \\
\hline
\end{tabular}

By interpreting the result from Haussman test above, with a $\mathrm{P}$ value $>0.05$, it means that the random effect would be more appropriate to be used. Due to the inconsistency of results obtained from both tests, the Lagrange-multiplier test needs to be performed.

Table 13

Lagrange-Multiplier test Result for Model 3

\begin{tabular}{|l|c|c|c|}
\hline Effect Test & Cross-section & $\begin{array}{c}\text { Test Hypothesis } \\
\text { Time }\end{array}$ & Both \\
\hline Breusch-Pagan & 213.5403 & 2.513736 & 216.0540 \\
\hline & $(0.0000)$ & $(0.1129)$ & $(0.0000)$ \\
\hline
\end{tabular}

The result above shows that the $\mathrm{P}$ value is $<0.05$ which concludes this test as choosing random effect as the appropriate model. From three tests above (Chow test, Haussman test, Lagrange-Multiplier test) it is concluded that the random effect would be used as a method to estimate statistical model 3 . 
Table 14

The Result of Model 3 for Hypothesis 2

\begin{tabular}{|l|c|c|c|c|}
\hline \multicolumn{5}{|c|}{ Dependent variable: CFA $(\mathrm{n}=920)$} \\
\hline \multicolumn{1}{|c|}{ Variable } & Coefficient & Standard Errors & t-statistic & Probability value \\
\hline C & -3.355813 & 1.148254 & -2.922535 & 0.0036 \\
\hline USD & 2.436131 & 7.136621 & 0.341356 & 0.7329 \\
\hline JPY & 9.575526 & 6.340469 & 1.510224 & 0.1313 \\
\hline EUR & -5.758665 & 3.909483 & -1.472999 & 0.1411 \\
\hline REER & $\mathbf{- 8 . 3 2 0 8 5 7}$ & $\mathbf{3 . 4 7 3 4 6 9}$ & $\mathbf{- 2 . 3 9 5 5 4 7}$ & $\mathbf{0 . 0 1 6 8}$ \\
\hline Assets & $\mathbf{1 . 9 4 4 9 9 8}$ & $\mathbf{0 . 0 9 2 4 9 9}$ & $\mathbf{2 1 . 0 2 7 2 3}$ & $\mathbf{0 . 0 0 0 0}$ \\
\hline Liabilities & 0.015648 & 0.023233 & 0.673531 & 0.5008 \\
\hline Adj. R-squared & & & & 0.366157 \\
\hline Durbin-Watson stat & & & & 1.827693 \\
\hline Prob (F-statistic) & & & & 0.000000 \\
\hline
\end{tabular}

After obtaining the statistic result, by looking at the Prob (F-statistic) of 0.000000 , it should have shown that all independent variable affects the dependent variable. However, looking closely to each independent variables $\mathrm{P}$ value, $\mathrm{H}_{2}$ is rejected due to them being not significant statistically for foreign currency volatility's proxy (USD, JPY, EUR) in this model.

Furthermore, from the result of testing Model 3, only REER has a significant effect on the dependent variable. The result regarding REER in Model 3 is also consistent with the results obtained from Model 2 that indicates a negative association to cash flows. However, we do not find any effect of individual foreign currency volatility to the cash flows in Model 3. This could be due to a smaller number of samples included in Model $3(\mathrm{n}=920)$ which is based annual cash-flow in the audited financial statements, compared to larger samples in Model $2(n=3,660)$ which is based on quarterly cash-flows. The insignificant results of USD, JPY, and EUR to annual cash flows may also indicate that the effect of foreign currency volatility is more pronounced to the more timely financial statements; the effect seems to dissipate over time in the annual financial statements. Concerning the control variables, assets show a positive and significant coefficient in Model 3, consistent with the result in Model 2. 


\section{Conclusion, Limitations, and Implications}

This study aims to examine whether foreign currency volatility affects stock return and cash flows of non-financial companies in Indonesia. This study also further tests the effect of market return and trading volume to companies' stock return as well as testing the effect of company size measured by total asset and liability to the movement of companies' cash flows. It also tests efficient market hypothesis theory with its information asymmetry assumption in Indonesia Stock Exchange, especially towards non-financial companies. An investing and valuation of companies by investors/public according to various information available held by them.

The results obtained may indicate Indonesia being a semi-strong form, where prices adjust to information available. However, even though companies may use foreign currencies in its operation to some extent, its volatility does not necessarily affect its stock return movement significantly. Furthermore, it may give the companies' more liquidity risks, which is would be categorized with transaction risk arises from companies' obligations to make or receive payments denominated in foreign currency in future, translation risk arises from translating foreign denominated currencies into home currencies particularly those which have foreign subsidiaries, and economic (operating) risks arises from unexpected currency fluctuation of the company's cash flow and market value.

The first hypothesis is not fully supported in this study. It directed to the conclusion that foreign currency volatility is not a big deciding factor in driving the movement of stock return, foreign currency volatilities might influence how investor value companies but not considered as a big influence towards stock price in Indonesia, it is supported by the fact that the R-squared value of 0.010979 obtained from Model 1 which is considerably small. It explains that the model does not have a reliable ability to estimate the relationship of the independent variables to stock return. However, from three foreign currencies employed, EUR (euro) stands out as having the most effect to stock return while the other proxy such as USD (US dollar), JPY 
(Japanese yen), and REER (Real Effective Exchange Rate) are not affecting companies' stock return significantly.

Control variables such as market return and trade volume have significant effect referring to its $\mathrm{P}$ value, and this finding is consistent with the theory of Efficient Market Hypothesis where both variables' information is publicly available, and it reflected on how investors value stocks because they can find it and interpreted it with ease.

Meanwhile, the second hypothesis was supported by the result obtained from Model 2 and Model 3. So, the regression test resulted in a significant relationship between the dependent variables (CFQ \& CFA) and independent variables. It is consistent with the findings from Bartram (2007) which stated the impact of foreign currency risk (volatility) on stock and cash flows is similar, even though in the first model foreign currency volatility don't have significant effect towards stock price, it has a similar impact to cash flows. According to results obtained from Model 1, EUR impacts stock return negatively. This result is coherent with the cash flows models. These findings are supported by the test result from Model 3 where annual cash flows (CFA) as the audited version of the second dependent variable quarter cash flows (CFQ). The result obtained from testing Model 2 and Model 3 provides a corresponding result with studies conducted by Booth \& Rotenberg (1990), Bartram (2008), and Atanasov \& Nitschka (2015) which stated that corporate cash flows are subject to foreign currency volatilities, and companies' future cash flow might be disturbed due to unexpected exchange rates changes.

Total Asset positively impacts the dependent variable both in Model 2 and Model 3. This supports the study by Widjaja and Kasenda (2008) that the amount asset owned by a company would help its flexibility and access to fund its operation and thus enhance its financial performance. Which would help companies improve its cash flows in a positive trend. 


\section{Limitations and Suggestions for Future Studies}

The limitations identified in this study are as follows. First, the research sample is still limited due to unavailability in gathering complete data for the intended proxies for certain companies. This might lead to the incompleteness of sample required that would represent the population studied. Due to the purposive sampling method, these companies were excluded from this study, even though there was a possibility for a more accurate estimation in the model. Second, this study excludes CNY (Chinese Yuan) as one of possible proxy for its independent variable, due to the existence of perfect multicollinearity with USD (US Dollar) in yearly time-frame even though China is a strong and influencing country in today's global economy. Thus, it is possible that there were certain viewpoints that this study missed. Third, the period studied for every variable only includes monthly, quarterly, and annual time-frame. This might result in capturing volatilities that exist within smaller time-frame.

Based on the limitations and constraints that have been disclosed above, there are suggestions for further improvements in executing future study regarding this topic. Further research could be able to cover the latest period which should have more complete data available. With the use of the latest study period and complete financial information should be able to provide a more accurate model to explain the phenomenon. Furthermore, future studies may test the volatility effect by employing more complex model/tools, such as GARCH/EGARCH to measure the volatilities and compare the results, thus enabling the analysis and interpretation from two different perspectives of the model.

\section{REFERENCES}

Andersen, Torben., Tim Bollerslev, Francis X. D., Paul L. 2001. "The Distribution of Realized Exchange Rate Volatility.” Journal of the American Statistical Association 96: 42-55.

Atanasov, Victoria, Thomas N. 2015. "Foreign Currency Returns and Systematic Risks." Journal of Financial and Quantitative Analysis 50: 231-250.

Bacha, O. I., Azhar M., Sharifah R. S. M. Z., Mohd E. S. R. 2013. "Foreign Currency Exposure and Impact of Policy Switch - the case of Malaysian listed firms." Applied Economics 45: 2974-2984. 
Bartram, Söhnke M. 2008. "What Lies Beneath: Foreign currency Rate Exposure, Hedging and Cash Flows." Journal of Banking \& Finance 32. No. 8: 1508-1521.

Bartram, Söhnke M. 2007. "Corporate Cash Flow and Stock Price Exposures to Foreign Currency Rate Risk." Journal of Corporate Finance 13. No. 5: 1-24.

Brigham, Eugene F., Houston, Joel F. 2010. Essentials of Financial Management Third Edition. Singapore, Cengage Learning Asia Pte Ltd.

Booth, Laurence, Wendy R. 1990. "Assessing Foreign Currency Exposure: Theory and Application Using Canadian Firms." Journal of International Financial Management and Accounting 2. No. 1: 1-22.

Cont, Rama. 2007. "Volatility Clustering in Financial Markets: Empirical Facts and AgentBased Models.” Long Memory in Economics 2: 289-309.

Demirgüç-Kunt, A., \& Levine, R. 1996. "Stock Markets, Corporate Finance, and Economic Growth: An Overview." The World Bank Economic Review, 10 No. 2: 223-239.

Fama, Eugene F. "Efficient Capital Markets: A Review of Theory and Empirical Work." Journal of Finance 25. No. 2: 383-417.

Gujarati, Damodar N., and Dawn C. Porter. 2010. Essentials of Econometrics Fourth Edition. New York, The McGraw-Hill Companies, Inc.

Hartono, Jogiyanto. 2015. "Teori Portfolio dan Analisis Investasi." Edisi Kesepuluh. BPFE: 264.

Hartono, Jogiyanto. 2011. "Metodologi Penelitian Bisnis, Salah Kaprah dan PengalamanPengalaman". BPFE: 62.

Gujarati, Damodar N. “Econometrics by Example”. 2012. Palgrave Macmillan.

Jia He, Lillian K. NG, Xueping Wu. 1997. "Foreign currency Exposure, Risk and the Japanese Stock Market." Applied Economics 45: 1-35.

Kelikume, Ikechukwu. 2016. "New Evidence from the Efficient Market Hypothesis for the Nigerian Stock Index Using the Wavelet Unit Root Test Approach". The Journal of Developing Areas 50. No. 2: 185-197.

Khalid, Shah, Arshad A., Qadar B. B., Nazim A. 2014. "Analysis of the Impact of Leverage on Various Measures of Corporate Performance, using Arellano and Bond Dynamic Panel Data Estimation Technique". Abasyn Journal of Social Sciences 7. No. 1: 1-10.

Korhonen, Marko. 2015. "The Relation between National Stock Prices and Effective Exchange Rates: Does it Affect Exchange Rate Exposure?” Global Economy Journal 15. No. 2: 241 $-256$.

Krause, Robert P. 2000. "Volatility Contracts ${ }^{\mathrm{TM}}$ - A New Alternative" The Journal of Alternative Investments 3. No. 1: 12-20. 
Kumar, V. Rajesh and Gowrisha J. 2014. "Testing Efficient Market Hypothesis in the Foreign Currency Market." International Journal of Research in Commerce \& Management 5. No. 8: 4-16.

Kwak, Sang G. and Jong H. K. 2017. "Central Limit Theorem: The Cornerstone of Modern Statistics." Korean Journal of Anesthesiology 70. No. 2: 144-156.

Ma, Christopher K., and Kao, G. Wenchi. 1990. "On Exchange Rate Changes and Stock Price Reactions." Journal of Business Finance \& Accounting 17. No. 3: 441-449.

Minjina, Dragos, Petre B. 2013. "Testing the Efficient Markets Hypothesis on the Romanian Capital Market." Academy of Economic Studies Bucharest 15: 151-158.

Nikita, Mirah Putu, Subiakto S. 2012. "Testing on Weak Form Market Efficiency: The Evidence from Indonesia Stock Market Year 2008-2011." $2^{\text {nd }}$ International Conference on Business, Economics, Management and Behavioral Sciences (BEMBS'2012): 56-60.

Oberndorfer, Ulrich. 2009. "Energy Prices, Volatility, and the Stock Market: Evidence from the Eurozone." Energy Policy 37. No. 12: 5787-5795.

Papaioannou, Michael. 2006. "Exchange Rate Risk Measurement and Management: Issues and Approaches for Firms.” IMF Working Paper: 3-4.

Reilly, Frank., Keith C. Brown. 2012. Investment Analysis \& Portfolio Management, Tenth Edition. USA, South-Western Cengage Learning.

Sahlian, Daniela, Mihalea B., Daniela L. T. 2013. "Fair Value Hedging, Between Opportunity and Necessity" Theoretical and Applied Economics XX No. 12(589): 97-104.

Sangany, Edward. 2015. "Effect of Foreign currency Exposure on Stock Returns for NonFinancial Institutions Listed on the Nairobi Securities Exchange.” pg 1-57.

Santoso, Singgih. 2000. "Latihan SPSS: Statistik Parametrik." Jakarta: Elex Media Komputindo.

Simarmata, S. M., and Hartono, J. 2016. "Perbandingan Volatilitas EWMA, GARCH dan Monte Carlo Terhadap Nilai Tukar Mata Uang Asing Bank BJB”. Jurnal Akuntansi dan Bisnis Krisnadwipayana 3. No. 2: 1-17.

Suciwati, Desak Putu, Mas'ud M. 2002. "Pengaruh Risiko Nilai Tukar Rupiah Terhadap Return Saham: Studi Empiris Pada Perusahaan Manufaktur Yang Terdaftar di BEJ." Jurnal Ekonomi dan Bisnis Indonesia 17. No. 4: 347-360.

Sulistyandari. 2011. "Hubungan Kausalitas Antara Nilai Tukar Mata Uang dan Indeks Harga Saham di Pasar Modal Indonesia.” Performance 13. No. 1: 103-127.

Tabachnick, B. G., and L. S. Fidell. 2007. "Multivariate Analysis of Variance and Covariance." Using Multivariate Statistics. No. 3: 402-407. 
The Indonesian Journal of Accounting Research - Sep, Vol. 21, No.3, 2018

Wei, Kelsey D., Laura T. Starks. 2013. "Foreign currency Exposure Elasticity and Financial Distress" Financial Management: 709-735.

Widjaja, Indra, and Faris K. 2008. "Pengaruh Kepemilikan Institusional, Aktiva Berwujud, Ukuran Perusahaan dan Profitibilitas Terhadap Struktur Modal pada Perusahaan dalam Industri Barang Konsumsi di BEI.” Jurnal Manajemen. Tahun XII, No. 2: 139-150. 
APPENDIX

Appendix 1 - List of Companies

\begin{tabular}{|c|c|c|c|c|c|}
\hline No. & Code & Company Name & No. & Code & Company Name \\
\hline 1 & AALI & Astra Agro Lestari TBK & 93 & KLBF & Kalbe Farma Tbk PT \\
\hline 2 & ABBA & PT Mahaka Media TBK & 94 & KRAS & $\begin{array}{l}\text { Krakatau Steel Persero } \\
\text { Tbk PT }\end{array}$ \\
\hline 3 & ACES & $\begin{array}{l}\text { Ace Hardware Indonesia } \\
\text { TBK, PT }\end{array}$ & 95 & LAPD & $\begin{array}{l}\text { Leyand International Tbk } \\
\text { PT }\end{array}$ \\
\hline 4 & ADES & $\begin{array}{l}\text { Akasha Wira International } \\
\text { TBK, PT }\end{array}$ & 96 & LMAS & $\begin{array}{l}\text { Limas Indonesia } \\
\text { Makmur Tbk PT }\end{array}$ \\
\hline 5 & ADHI & Adhi Karya Persero TBK, PT & 97 & LMPI & $\begin{array}{l}\text { Langgeng Makmur } \\
\text { Industri Tbk PT }\end{array}$ \\
\hline 6 & ADMG & $\begin{array}{l}\text { Polychem Indonesia TBK, } \\
\text { PT }\end{array}$ & 98 & LMSH & Lionmesh Prima Tbk PT \\
\hline 7 & ADRO & Adaro Energy TBK PT & 99 & LPPF & $\begin{array}{l}\text { Matahari Department } \\
\text { Store Tbk PT }\end{array}$ \\
\hline 8 & AIMS & $\begin{array}{l}\text { Akbar Indo Makmur Stimec } \\
\text { TBK PT }\end{array}$ & 100 & LTLS & Lautan Luas Tbk PT \\
\hline 9 & AISA & $\begin{array}{l}\text { Tiga Pilar Sejahtera Food } \\
\text { TBK PT }\end{array}$ & 101 & MAIN & $\begin{array}{l}\text { Malindo Feedmill Tbk } \\
\text { PT }\end{array}$ \\
\hline 10 & AKPI & $\begin{array}{l}\text { Argha Karya Prima Industry } \\
\text { TBK PT }\end{array}$ & 102 & MAMI & $\begin{array}{l}\text { Mas Murni Indonesia } \\
\text { Tbk PT }\end{array}$ \\
\hline 11 & AKRA & AKR Corporindo TBK PT & 103 & MAPI & Mitra Adiperkasa Tbk PT \\
\hline 12 & ALKA & Alakasa Industrindo TBK PT & 104 & MASA & $\begin{array}{l}\text { Multistrada Arah Sarana } \\
\text { Tbk PT }\end{array}$ \\
\hline 13 & ALMI & $\begin{array}{l}\text { Alumindo Light Metal } \\
\text { Industri TBK PT }\end{array}$ & 105 & MBTO & Martina Berto Tbk PT \\
\hline 14 & AMRT & $\begin{array}{l}\text { Sumber Alfaria Trijaya TBK } \\
\text { PT }\end{array}$ & 106 & MDRN & $\begin{array}{l}\text { Modern Internasional } \\
\text { Tbk PT }\end{array}$ \\
\hline 15 & APOL & $\begin{array}{l}\text { Arpeni Pratama Ocean Line } \\
\text { TBK PT }\end{array}$ & 107 & MEDC & $\begin{array}{l}\text { Medco Energi } \\
\text { Internasional Tbk PT }\end{array}$ \\
\hline 16 & ARNA & Arwana Citramulia TBK PT & 108 & META & $\begin{array}{l}\text { Nusantara Infrastructure } \\
\text { Tbk PT }\end{array}$ \\
\hline 17 & ARTI & Ratu Prabu Energi TBK PT & 109 & MFMI & $\begin{array}{l}\text { Multifiling Mitra } \\
\text { Indonesia Tbk PT }\end{array}$ \\
\hline 18 & ASII & Astra International TBK PT & 110 & MICE & Multi Indocitra Tbk PT \\
\hline 19 & AUTO & Astra Otoparts TBK PT & 112 & MIDI & $\begin{array}{l}\text { Midi Utama Indonesia } \\
\text { Tbk PT }\end{array}$ \\
\hline 20 & BAYU & Bayu Buana TBK PT & 113 & MIRA & $\begin{array}{l}\text { Mitra International } \\
\text { Resources Tbk PT }\end{array}$ \\
\hline 21 & BIMA & $\begin{array}{l}\text { Primarindo Asia } \\
\text { Infrastructure TBK PT }\end{array}$ & 114 & MLIA & $\begin{array}{l}\text { Mulia Industrindo Tbk } \\
\text { PT }\end{array}$ \\
\hline 22 & BIPI & Benakat Integra TBK PT & 115 & MLPL & Multipolar Tbk PT \\
\hline 23 & BISI & BISI International TBK PT & 116 & MNCN & $\begin{array}{l}\text { Media Nusantara Citra } \\
\text { Tbk PT }\end{array}$ \\
\hline 24 & BMTR & Global Mediacom TBK PT & 117 & MPPA & Matahari Putra Prima \\
\hline
\end{tabular}




\begin{tabular}{|c|c|c|c|c|c|}
\hline & & & & & Tbk PT \\
\hline 25 & BNBR & Bakrie and Brothers TBK PT & 118 & MRAT & Mustika Ratu Tbk PT \\
\hline 26 & BRAM & Indo Kordsa TBK PT & 119 & MTDL & $\begin{array}{l}\text { Metrodata Electronics } \\
\text { Tbk PT }\end{array}$ \\
\hline 27 & BRNA & Berlina TBK PT & 120 & MYOR & Mayora Indah Tbk PT \\
\hline 28 & BRPT & Barito Pacific TBK PT & 121 & MYTX & $\begin{array}{l}\text { Hanson International Tbk } \\
\text { PT }\end{array}$ \\
\hline 29 & BTEK & $\begin{array}{l}\text { Bumi Teknokultura Unggul } \\
\text { TBK PT }\end{array}$ & 122 & NIPS & Nipress Tbk PT \\
\hline 30 & BUDI & $\begin{array}{l}\text { Budi Starch \& Sweetener } \\
\text { TBK PT }\end{array}$ & 123 & PANR & $\begin{array}{l}\text { Panorama Sentrawisata } \\
\text { Tbk PT }\end{array}$ \\
\hline 31 & BUMI & Bumi Resources TBK PT & 124 & PDES & $\begin{array}{l}\text { Destinasi Tirta Nusantara } \\
\text { Tbk PT }\end{array}$ \\
\hline 32 & BWPT & $\begin{array}{l}\text { Eagle High Plantations TBK } \\
\text { PT }\end{array}$ & 125 & PGAS & $\begin{array}{l}\text { Perusahaan Gas Negara } \\
\text { Persero Tbk }\end{array}$ \\
\hline 33 & BYAN & Bayan Resources TBK PT & 126 & PGLI & $\begin{array}{l}\text { Pembangunan Graha } \\
\text { Lestari Tbk PT }\end{array}$ \\
\hline 34 & CITA & $\begin{array}{l}\text { Cita Mineral Investindo TBK } \\
\text { PT }\end{array}$ & 127 & PJAA & $\begin{array}{l}\text { Pembangunan Jaya } \\
\text { Ancol Tbk PT }\end{array}$ \\
\hline 35 & CKRA & Cakra Mineral TBK PT & 128 & PKPK & $\begin{array}{l}\text { Perdana Karya Perkasa } \\
\text { Tbk PT }\end{array}$ \\
\hline 36 & CLPI & Colorpak Indonesia TBK PT & 129 & PLIN & $\begin{array}{l}\text { Plaza Indonesia Realty } \\
\text { Tbk PT }\end{array}$ \\
\hline 37 & CMNP & $\begin{array}{l}\text { Citra Marga Nusaphala } \\
\text { Persada TBK PT }\end{array}$ & 130 & PNSE & Pudjiadi \& Sons Tbk PT \\
\hline 38 & CMPP & $\begin{array}{l}\text { Rimau Multi Putra Pratama } \\
\text { TBK PT }\end{array}$ & 131 & PRAS & $\begin{array}{l}\text { Prima Alloy Steel } \\
\text { Universal Tbk PT }\end{array}$ \\
\hline 39 & $\mathrm{CNKO}$ & $\begin{array}{l}\text { Exploitasi Energi Indonesia } \\
\text { TBK PT }\end{array}$ & 132 & PSAB & $\begin{array}{l}\text { J Resources Asia Pasific } \\
\text { Tbk PT }\end{array}$ \\
\hline 40 & CPIN & $\begin{array}{l}\text { Charoen Pokphand Indonesia } \\
\text { TBK PT }\end{array}$ & 133 & PSDN & $\begin{array}{l}\text { Prasidha Aneka Niaga } \\
\text { Tbk PT }\end{array}$ \\
\hline 41 & CSAP & $\begin{array}{l}\text { Catur Sentosa Adiprana TBK } \\
\text { PT }\end{array}$ & 134 & PTBA & $\begin{array}{l}\text { Bukit Asam Persero Tbk } \\
\text { PT }\end{array}$ \\
\hline 42 & CTBN & Citra Tubindo TBK PT & 135 & PTPP & PP Persero Tbk PT \\
\hline 43 & CTTH & Citatah TBK PT & 136 & PTRO & Petrosea Tbk PT \\
\hline 44 & DEWA & Darma Henwa TBK PT & 137 & PTSP & $\begin{array}{l}\text { Pioneerindo Gourmet } \\
\text { International Tbk PT }\end{array}$ \\
\hline 45 & DGIK & $\begin{array}{l}\text { Nusa Konstruksi Enjiniring } \\
\text { TBK PT }\end{array}$ & 138 & PUDP & Pudjiadi Prestige Tbk PT \\
\hline 46 & DSFI & $\begin{array}{l}\text { Dharma Samudera Fishing } \\
\text { Industries Tbk PT }\end{array}$ & 139 & PYFA & Pyridam Farma Tbk PT \\
\hline 47 & DSSA & $\begin{array}{l}\text { Dian Swastatika Sentosa Tbk } \\
\text { PT }\end{array}$ & 140 & RAJA & Rukun Raharja Tbk PT \\
\hline 48 & EKAD & $\begin{array}{l}\text { Ekadharma International Tbk } \\
\text { PT }\end{array}$ & 141 & RICY & $\begin{array}{l}\text { Ricky Putra Globalindo } \\
\text { Tbk PT }\end{array}$ \\
\hline 49 & ELSA & Elnusa Tbk PT & 142 & ROTI & $\begin{array}{l}\text { Nippon Indosari } \\
\text { Corpindo Tbk PT }\end{array}$ \\
\hline 50 & EMTK & Elang Mahkota Teknologi & 143 & RUIS & Radiant Utama Interinsco \\
\hline
\end{tabular}




\begin{tabular}{|c|c|c|c|c|c|}
\hline & & Tbk PT & & & Tbk PT \\
\hline 51 & ETWA & $\begin{array}{l}\text { Eterindo Wahanatama Tbk } \\
\text { PT }\end{array}$ & 144 & SAFE & Steady Safe Tbk PT \\
\hline 52 & EXCL & XL Axiata Tbk PT & 145 & SCMA & $\begin{array}{l}\text { Surya Citra Media Tbk } \\
\text { PT }\end{array}$ \\
\hline 53 & FAST & Fast Food Indonesia Tbk PT & 146 & SDPC & $\begin{array}{l}\text { Millennium Pharmacon } \\
\text { International Tbk PT }\end{array}$ \\
\hline 54 & FASW & Fajar Surya Wisesa Tbk PT & 147 & SGRO & Sampoerna Agro PT \\
\hline 55 & FORU & Fortune Indonesia Tbk PT & 148 & SHID & $\begin{array}{l}\text { Hotel Sahid Jaya } \\
\text { International Tbk PT }\end{array}$ \\
\hline 56 & FPNI & Lotte Chemical Titan Tbk PT & 149 & SIAP & $\begin{array}{l}\text { Sekawan Intipratama } \\
\text { Tbk PT }\end{array}$ \\
\hline 57 & GDYR & Goodyear Indonesia Tbk PT & 150 & SIPD & Sierad Produce Tbk PT \\
\hline 58 & GEMA & Gema Grahasarana Tbk PT & 151 & SKLT & Sekar Laut Tbk PT \\
\hline 59 & GIAA & $\begin{array}{l}\text { Garuda Indonesia Persero } \\
\text { Tbk PT }\end{array}$ & 152 & SMAR & $\begin{array}{l}\text { Sinar Mas Agro } \\
\text { Resources \& Technology } \\
\text { Tbk PT }\end{array}$ \\
\hline 60 & GJTL & Gajah Tunggal Tbk PT & 153 & SMCB & $\begin{array}{l}\text { Holcim Indonesia Tbk } \\
\text { PT }\end{array}$ \\
\hline 61 & GMCW & $\begin{array}{l}\text { Grahamas Citrawisata Tbk } \\
\text { PT }\end{array}$ & 154 & SMGR & $\begin{array}{l}\text { Semen Indonesia Persero } \\
\text { Tbk PT }\end{array}$ \\
\hline 62 & GZCO & Gozco Plantations Tbk PT & 155 & SMMT & $\begin{array}{l}\text { Golden Eagle Energy } \\
\text { Tbk PT }\end{array}$ \\
\hline 63 & HDTX & $\begin{array}{l}\text { Panasia Indo Resources Tbk } \\
\text { PT }\end{array}$ & 156 & SMSM & $\begin{array}{l}\text { Selamat Sempurna Tbk } \\
\text { PT }\end{array}$ \\
\hline 64 & HOME & $\begin{array}{l}\text { Hotel Mandarine Regency } \\
\text { Tbk PT }\end{array}$ & 157 & SONA & $\begin{array}{l}\text { Sona Topas Tourism } \\
\text { Industry Tbk PT }\end{array}$ \\
\hline 65 & IATA & $\begin{array}{l}\text { Indonesia Transport \& } \\
\text { Infrastructure Tbk PT }\end{array}$ & 158 & SPMA & Suparma Tbk PT \\
\hline 66 & ICBP & $\begin{array}{l}\text { Indofood CBP Sukses } \\
\text { Makmur Tbk PT }\end{array}$ & 159 & SQMI & Renuka Coalindo Tbk PT \\
\hline 67 & IIKP & Inti Agri Resources Tbk PT & 160 & SRSN & Indo Acidatama Tbk PT \\
\hline 68 & IKAI & $\begin{array}{l}\text { Intikeramik Alamasri Industri } \\
\text { Tbk PT }\end{array}$ & 161 & SSIA & $\begin{array}{l}\text { Surya Semesta Internusa } \\
\text { Tbk PT }\end{array}$ \\
\hline 69 & INAF & Indofarma Persero Tbk PT & 162 & SSTM & $\begin{array}{l}\text { Sunson Textile } \\
\text { Manufacturer Tbk PT }\end{array}$ \\
\hline 70 & INAI & $\begin{array}{l}\text { Indal Aluminum Industry } \\
\text { Tbk PT }\end{array}$ & 163 & SUGI & Sugih Energy Tbk PT \\
\hline 71 & INCI & $\begin{array}{l}\text { Intanwijaya Internasional } \\
\text { Tbk PT }\end{array}$ & 164 & TIRT & $\begin{array}{l}\text { Tirta Mahakam } \\
\text { Resources Tbk PT }\end{array}$ \\
\hline 72 & INCO & Vale Indonesia Tbk PT & 165 & TKIM & $\begin{array}{l}\text { Pabrik Kertas Tjiwi } \\
\text { Kimia Tbk PT }\end{array}$ \\
\hline 73 & INDS & Indospring Tbk PT & 166 & TLKM & $\begin{array}{l}\text { Telekomunikasi } \\
\text { Indonesia Persero Tbk } \\
\text { PT }\end{array}$ \\
\hline 74 & INDY & Indika Energy Tbk PT & 167 & TMAS & $\begin{array}{l}\text { Pelayaran Tempuran } \\
\text { Emas Tbk PT }\end{array}$ \\
\hline 75 & INKP & Indah Kiat Pulp \& Paper & 168 & TMPO & Tempo Inti Media Tbk \\
\hline
\end{tabular}




\begin{tabular}{|c|c|c|c|c|c|}
\hline & & Corp Tbk PT & & & PT \\
\hline 76 & INRU & Toba Pulp Lestari Tbk PT & 169 & TOTL & $\begin{array}{l}\text { Total Bangun Persada } \\
\text { Tbk PT }\end{array}$ \\
\hline 77 & INTA & Intraco Penta Tbk PT & 170 & TOWR & $\begin{array}{l}\text { Sarana Menara } \\
\text { Nusantara Tbk PT }\end{array}$ \\
\hline 78 & INTD & Inter Delta Tbk PT & 171 & TPIA & $\begin{array}{l}\text { Chandra Asri } \\
\text { Petrochemical Tbk PT }\end{array}$ \\
\hline 79 & INTP & $\begin{array}{l}\text { Indocement Tunggal } \\
\text { Prakarsa Tbk PT }\end{array}$ & 172 & TRIL & $\begin{array}{l}\text { Triwira Insanlestari Tbk } \\
\text { PT }\end{array}$ \\
\hline 80 & ISAT & Indosat Tbk PT & 173 & TRST & Trias Sentosa Tbk PT \\
\hline 81 & JECC & Jembo Cable Co Tbk PT & 174 & TRUB & $\begin{array}{l}\text { Truba Alam Manunggal } \\
\text { Engineering PT }\end{array}$ \\
\hline 82 & JPFA & $\begin{array}{l}\text { Japfa Comfeed Indonesia } \\
\text { Tbk PT }\end{array}$ & 175 & TSPC & $\begin{array}{l}\text { Tempo Scan Pacific Tbk } \\
\text { PT }\end{array}$ \\
\hline 83 & JSMR & Jasa Marga Persero Tbk PT & 176 & TURI & Tunas Ridean Tbk PT \\
\hline 84 & JSPT & $\begin{array}{l}\text { Jakarta Setiabudi } \\
\text { Internasional Tbk PT }\end{array}$ & 177 & ULTJ & $\begin{array}{l}\text { Ultrajaya Milk Industry } \\
\text { \& Trading Co Tbk PT }\end{array}$ \\
\hline 85 & JTPE & Jasuindo Tiga Perkasa Tbk & 178 & UNIC & $\begin{array}{l}\text { Unggul Indah Cahaya } \\
\text { Tbk PT }\end{array}$ \\
\hline 86 & KAEF & Kimia Farma Persero Tbk PT & 179 & UNSP & $\begin{array}{l}\text { Bakrie Sumatera } \\
\text { Plantations Tbk PT }\end{array}$ \\
\hline 87 & KBLI & KMI Wire \& Cable Tbk PT & 180 & UNTR & United Tractors Tbk PT \\
\hline 88 & KBLV & First Media Tbk PT & 181 & WAPO & $\begin{array}{l}\text { Wahana Pronatural Tbk } \\
\text { PT }\end{array}$ \\
\hline 89 & KBRI & $\begin{array}{l}\text { Kertas Basuki Rachmat } \\
\text { Indonesia Tbk PT }\end{array}$ & 182 & WEHA & $\begin{array}{l}\text { Weha Transportasi } \\
\text { Indonesia Tbk PT }\end{array}$ \\
\hline 90 & KDSI & $\begin{array}{l}\text { Kedawung Setia Industrial } \\
\text { Tbk PT }\end{array}$ & 183 & WIKA & $\begin{array}{l}\text { Wijaya Karya Persero } \\
\text { Tbk PT }\end{array}$ \\
\hline 91 & KKGI & $\begin{array}{l}\text { Resource Alam Indonesia } \\
\text { Tbk PT }\end{array}$ & 184 & YPAS & $\begin{array}{l}\text { Yanaprima Hastapersada } \\
\text { Tbk PT }\end{array}$ \\
\hline 92 & ZBRA & Zebra Nusantara Tbk PT & & & \\
\hline
\end{tabular}

